\title{
Proximate composition and antioxidant potential of selected tubers peel
}

\author{
Dusuki, N.J.S., *Abu Bakar, M.F., Abu Bakar, F.I., Ismail, N.A. and Azman, M.I. \\ Centre of Research for Sustainable Uses of Natural Resources (CoR-SUNR), Faculty of Applied Sciences \\ and Technology, Universiti Tun Hussein Onn Malaysia (UTHM), Hab Pendidikan Tinggi Pagoh, KM 1, \\ Jalan Panchor, 84600 Muar, Johor, Malaysia
}

\begin{abstract}
Article history:
Received: 12 May 2019

Received in revised form: 16 June 2019

Accepted: 17 June 2019

Available Online: 1 August 2019
\end{abstract}

Keywords:

Ipomoea batatas,

Manihot esculenta,

Antioxidant,

Phytochemical,

Nutritional composition

DOI:

https://doi.org/10.26656/fr.2017.4(1).178

\begin{abstract}
This study is aimed to investigate the nutritional composition, phytochemicals and antioxidant activity of red and purple variety of Ipomoea batatas (sweet potato) peels and Manihot esculenta (cassava) periderm and cortex layers. The proximate composition (carbohydrate, protein, fat, moisture, ash and minerals) was determined using standard methods while phytochemical contents (phenolic, flavonoid, anthocyanin and carotenoid) and antioxidant activity [2,2-diphenylpicrylhydrazyl (DPPH), ferric reducing antioxidant power (FRAP), and 2,2'-azino-bis(3-ethylbenzothiazoline-6-sulphonic acid) (ABTS) assays] were determined spectrophotometrically. Proximate analysis showed that both $I$. batatas and M. esculenta contained high carbohydrate content ranged from $75.07 \%$ to $87.04 \%$ but zero protein and low-fat contents $(0.83-2.2 \%)$. For the mineral contents, $I$. batatas contained higher potassium, sodium, iron and magnesium than $M$. esculenta. However, calcium was found higher in M. esculenta as compared to I. batatas. For the phytochemical study, total anthocyanin content showed the lowest value (0.43-3.08 $\mu \mathrm{g}$ c-3 -gE/g) for both tubers as compared to total phenolic (37.28-71.79 $\mu \mathrm{g}$ GAE/g), flavonoid (4.98-16.50 $\mu \mathrm{g} \mathrm{RE} / \mathrm{g})$ and carotenoid (14.54-46.66 $\mu \mathrm{g} \mathrm{BC/g}$ ) contents. For the antioxidant study, both purple and red variety of $I$. batatas showed higher percentages of inhibition using DPPH assay with $87.93 \%$ and $87.62 \%$, respectively compared to M. esculenta. Meanwhile, FRAP assay displayed lower values than ABTS assay for both tubers. In conclusion, both tubers, I. batatas and M. esculenta have close values of nutritional compositions. However, I. batatas showed higher mineral contents (potassium, iron, magnesium and sodium) and antioxidant activity than $M$. esculenta. For the phytochemical content, I. batatas contained higher total flavonoid and total anthocyanin contents while $M$. esculenta contained higher total phenolic and carotenoid contents. Hence, this study suggested that tuber's by-products have great potential for use in functional food as they are cheap and readily available as well as reducing waste disposal.
\end{abstract}

\section{Introduction}

Tubers are generally known as one of the important staple crops for human consumption. Sweet potato (Ipomoea batatas) and cassava (Manihot esculenta) has been ranked in top five most important crops on a fresh weight basis in developing countries together with rice, maize, and corn (Nawiri et al., 2013). Different tubers grow widely in different countries and conditions based on a few factors such as soil composition and climate. With a different environment, the composition of the tubers may vary due to the factors mentioned. Plants including tubers are potential source of natural antioxidants and act as secondary metabolites. Antioxidants can be found not only in the flesh but also in the peel of the tubers. Natural antioxidants or phytochemical antioxidants such as phenolic, flavonoid, anthocyanin, and carotenoid possess many functions such as prevent deterioration of the tubers, thus extending its shelf life. In addition, antioxidants have the ability in reducing the risk of diseases such as cancer. The searching for natural antioxidants to be used in the industry has increased due to its low toxicity, safe, and generally accepted (Ghasemzadeh et al., 2012).

Over years, consumption of fresh tubers has been decreasing as more tubers are peeled and processed into value-added products such as mashed potatoes, fries, and chips to meet demand from the consumers who want fast and convenience food. Large quantities of peels disposal 
have been concerned and looked into consideration especially towards environmental sustainability. For these reasons, this research aims to investigate the nutritional composition, phytochemicals and antioxidant activity of red and purple variety of sweet potatoes ( $I$. batatas) peels and the periderm and cortex layer of cassava (M. esculenta).

\section{Materials and methods}

\subsection{Sample preparation}

The tubers were washed, cleaned and peeled. The peels were dried for $48 \mathrm{hrs}$ at $55^{\circ} \mathrm{C}$ in the oven until there was no change in weight of the peels. The peels were ground into powder form, placed in zip lock polyethylene bags and left at $4{ }^{\circ} \mathrm{C}$ in the refrigerator until further analysis.

\subsection{Sample extraction}

Peels powder of $0.01 \mathrm{~g}$ was mixed with $100 \mathrm{~mL}$ of methanol, agitated for an hour and filtered using Whatman filter paper. Each test was done in triplicate to ensure the accuracy of the results (Wong et al., 2006).

\subsection{Proximate analysis}

Determination of moisture content was done using moisture analyser. At the end of the experiment, the percentage of moisture content was recorded (Nielsen, 2010). Carbohydrate content was determined according to AOAC (1995) and Anhwange (2008). The carbohydrate value was calculated using this formula: Percentage of carbohydrates $(\%)=100 \%$ - (moisture content $(\%)+$ Crude fat content $(\%)+$ Crude protein content $(\%)+$ Ash content $(\%)$. Analysis of protein was done using the Kjeldahl method involving three steps (i.e. digestion, distillation, and titration). The results of the protein content were obtained directly from the machine in percentage (\%) value (AOAC, 1995). Fat analysis was done according to Soxhlet method (AOAC, 1975). The percentage of fat content was calculated using this following equation: $\%$ Fat $=($ Weight before extraction - Weight after extraction)/(Sample weight) $\mathrm{x}$ $100 \%$. For the determination of ash content, $1 \mathrm{~g}$ of dried samples were placed in a furnace, $550^{\circ} \mathrm{C}$ up to $10 \mathrm{hrs}$ until ash was obtained (Abbasi et al., 2014). The ash content was calculated by using this equation: $\%$ Ash $=$ (W3-W1)/W2 x 100\% where W1 = weight of oven-dried empty crucible, $\mathrm{W} 2$ = weight of sample, and $\mathrm{W} 3=$ weight of ash and crucible.

\subsection{Determination of mineral content}

Mineral content was determined using the atomic absorption spectrophotometer, Perkin Elmer PinAAcle 900F (AOAC, 2005).

\subsection{Determination of phytochemical content}

\subsubsection{Total phenolic content}

Total phenolic content was determined as described by Hassan and Bakar (2013). The absorbance values were measured spectrophotometrically at $750 \mathrm{~nm}$. Gallic acid was used to make a calibration curve and the value obtained from the equation was expressed as $\mu \mathrm{g}$ gallic acid equivalents per $\mathrm{g}(\mu \mathrm{g} \mathrm{GAE} / \mathrm{g})$.

\subsubsection{Total flavonoid content}

Total flavonoid content was determined using the colorimetric aluminium chloride method (Elfalleh et al., 2012). The absorbance values were measured spectrophotometrically at $430 \mathrm{~nm}$. Rutin was used to make a calibration curve. Total flavonoid content of the sample was expressed as $\mu \mathrm{g}$ rutin equivalents per gram ( $\mu \mathrm{g} \mathrm{RE} / \mathrm{g}$ ).

\subsubsection{Total anthocyanin content}

Total anthocyanin content was determined by the $\mathrm{pH}$ differential method (Abu Bakar et al., 2016). The results were expressed as $\mu \mathrm{g}$ of cyanidin-3-glucoside equivalents per $\mathrm{g}(\mu \mathrm{g} \mathrm{CGE} / \mathrm{g})$. The total anthocyanin content was calculated with the following equation:

Total anthocyanin content $(\mu \mathrm{g} / \mathrm{g})=(\mathrm{A} \times \mathrm{Mw} \times \mathrm{DF} \times 10) /$ $(\varepsilon \times C)$

Where $A$ is the absorbance $=[(A 510 \mathrm{~nm}-\mathrm{A} 700 \mathrm{~nm})$ pH1.0 - (A510 nm - A700 nm)pH4.5]; MW is molecular weight for cyanidin-3-glucoside $=449.2$; DF is a dilution factor of the samples; $\varepsilon$ is the molar absorptivity of cyaniding-3-glucoside $=26,900$; and $C$ is the concentration of the buffer in $\mathrm{mg} / \mathrm{mL}$.

\subsubsection{Total carotenoid content}

Total carotenoid content was measured at $350 \mathrm{~nm}$ by using spectrophotometer (Abu Bakar et al., 2016). $\beta$ carotene was used to form a calibration curve and the results were expressed as $\mu \mathrm{g}$ of $\beta$ carotene equivalent per g sample $(\mu \mathrm{g} \mathrm{BC} / \mathrm{g})$.

\subsection{Determination of antioxidant activity}

\subsubsection{2,2-diphenyl-1-picrylhydrazyl (DPPH)}

A total of $5.9 \mathrm{mg}$ of DPPH powder was mixed with $100 \mathrm{~mL}$ of methanol. Then, $3 \mathrm{~mL}$ of the DPPH solution was added into $100 \mu \mathrm{L}$ of the sample. The sample was left for 15 mins in dark room before being read at an absorbance of $517 \mathrm{~nm}$ against blank using spectrophotometer. The equation below was used to determine the radical scavenging activity (Miliauskas et al., 2004).

Scavenging activity $(\%)=(1-($ Absorbance of sample/ 
Absorbance of control) x 100\%)

\subsubsection{Ferric reducing antioxidant power (FRAP)}

FRAP assay was measured spectrophotometrically at $595 \mathrm{~nm}$ (Lusia et al., 2015). The results were expressed as millimoles ferric ion reduced per gram of sample $(\mathrm{mM}$ $\mathrm{FE} / \mathrm{g})$.

\subsubsection{ABTS (2,2'-azinobis (3-ethylbenzthiazoline)-6- sulphonic acid) radical scavenging assay}

ABTS radical cation decolorization assay was done according to Re et al. (1999). The absorbance was measured at $734 \mathrm{~nm}$ using a spectrophotometer.

\subsection{Statistical analysis}

All the results were expressed as mean \pm standard deviation of triplicate in three independent experiments. Data were assessed by a one-way Analysis of Variance (ANOVA) where the mean values were considered significantly different when the value of $p<0.05$ was obtained using Statistical Package for the Social Sciences (SPSS) software.

\section{Results and discussion}

\subsection{Nutritional composition}

Tubers are always known as a rich starchy food. The results of the proximate composition of the tubers peel are presented in Table 1 while the mineral contents of the peels are presented in Table 2. The peels of I. batatas and $M$. esculenta showed significant values of carbohydrate content $(\mathrm{p}<0.05)$ as compared to the other components. The percentage values ranged from $75.07 \%$ to $87.04 \%$ with the peels of $M$. esculenta had a slightly higher amount of carbohydrate than I. batatas. On the other hand, protein content had been found to be $0 \%$ for both tubers, I. batatas. and M. esculenta. The fat and moisture contents of both $I$. batatas and M. esculenta were almost similar and found to be very low ranging from $0.83 \%$ to $2.2 \%$ and $5.77 \%$ to $7.17 \%$, respectively. For the ash content, I. batatas (purple and red varieties) had the higher percentage value with $16.96 \%$ and $14.18 \%$ as compared to that of $M$. esculenta (4.46$9.24 \%$ ) with all the samples tested showed significantly different $(\mathrm{p}<0.05)$.

A study was done by Aro et al. (2010) on the $M$. esculenta peels collected in Nigeria showed that the protein, fat, ash and moisture contents of $4.2 \%, 3.26 \%$, $7.47 \%$ and $82.1 \%$, respectively whereby the protein, fat and moisture contents of $M$. esculenta peels were higher than that of $M$. esculenta cortex and periderm layers in this study except for the ash content. The different results obtained were due to the different parts used. In 2010, Adeyosoye et al. showed that I. batatas peels contained $3.06 \%$ protein content and $7.00 \%$ fat content which were higher compared to I. batatas peels for both red and purple varieties in this study. However, the carbohydrate content of $I$. batatas peels in this current study (red variety: $78.3 \%$, purple variety: $75.07 \%$ ) were almost similar with the previous study with the value of $78.94 \%$ (Adeyosoye et al., 2010). Few factors such as genetic origin, geographical sources, the level of soil fertility and the harvesting periods might cause a variation in the proximate analysis results (Bhandari et al., 2003).

Ash composition is very important in determining minerals content (Nollet, 2004). Table 2 indicates the mineral contents for I. batatas and M. esculenta such as zinc, potassium, sodium, calcium, iron, and magnesium. Based on the results obtained, all the samples tested showed significantly different $(\mathrm{p}<0.05)$ between each other. Calcium was the most abundant minerals found in all the samples tested ranging from $85.82 \mathrm{mg} / \mathrm{L}$ to 116.3 $\mathrm{mg} / \mathrm{L}$ except for I. batatas (purple variety). However, $I$. batatas (purple variety) had the highest amount of iron

Table 1. Proximate composition of the tubers peel in (\%)

\begin{tabular}{cccccc}
\hline Sample & \multicolumn{5}{c}{ Constituents (\%) } \\
\cline { 2 - 6 } & Carbohydrate & Protein & Fat & Moisture & Ash \\
\hline Ipomoea batatas (red variety) & 78.3 & $0 \pm 0.00$ & $0.83 \pm 0.06$ & $6.69 \pm 0.31$ & $14.18 \pm 0.84$ \\
Ipomoea batatas (purple variety) & 75.07 & $0 \pm 0.00$ & $1.77 \pm 0.21$ & $6.02 \pm 0.42$ & $16.96 \pm 0.33$ \\
Manihot esculenta (periderm layer) & 87.04 & $0 \pm 0.00$ & $1.33 \pm 0.15$ & $7.17 \pm 1.27$ & $4.46 \pm 0.09$ \\
Manihot esculenta (cortex layer) & 82.79 & $0 \pm 0.00$ & $2.2 \pm 0.2$ & $5.77 \pm 0.07$ & $9.24 \pm 0.19$ \\
\hline
\end{tabular}

The results were expressed as mean \pm standard deviation in triplicate

Table 2. The minerals content of the tubers peel in $(\mathrm{mg} / \mathrm{L})$

\begin{tabular}{ccccccc}
\hline \multirow{2}{*}{ Samples } & \multicolumn{5}{c}{ Mineral content (mg/L) } \\
\cline { 2 - 7 } & Zinc & Potassium & Sodium & Calcium & Iron & Magnesium \\
\hline Ipomoea batatas (red variety) & $0 \pm 0.00$ & $19.38 \pm 0.03$ & $1.62 \pm 0.53$ & $100.2 \pm 0.85$ & $63.46 \pm 12.20$ & $3.12 \pm 0.02$ \\
Ipomoea batatas (purple variety) & $0 \pm 0.00$ & $19.49 \pm 0.01$ & $5.6 \pm 1.56$ & $62.62 \pm 2.06$ & $62.71 \pm 8.59$ & $3.07 \pm 0.02$ \\
Manihot esculenta (periderm layer) & $0 \pm 0.00$ & $11.61 \pm 0.01$ & $2.2 \pm 0.24$ & $85.82 \pm 1.32$ & $44.94 \pm 5.36$ & $2.78 \pm 0.02$ \\
Manihot esculenta (cortex layer) & $0.27 \pm 0.04$ & $11.67 \pm 0.02$ & $0.99 \pm 0.39$ & $116.3 \pm 0.8$ & $6.12 \pm 1.2$ & $3.05 \pm 0.02$ \\
\hline
\end{tabular}

The results were expressed as mean \pm standard deviation in triplicate 
Table 3. The phytochemical content of the tubers peel

\begin{tabular}{ccccc}
\hline \multirow{2}{*}{ Sample } & \multicolumn{4}{c}{ Phytochemical content } \\
\cline { 2 - 5 } & $\begin{array}{c}\text { Total phenolic content } \\
(\mu \mathrm{g} \mathrm{GAE} / \mathrm{g})\end{array}$ & $\begin{array}{c}\text { Total flavonoid } \\
\text { content } \\
(\mu \mathrm{g} \mathrm{RE} / \mathrm{g})\end{array}$ & $\begin{array}{c}\text { Total anthocyanin } \\
\text { content }(\mu \mathrm{g} \mathrm{c}-3-\mathrm{gE} / \mathrm{g})\end{array}$ & $\begin{array}{c}\text { Total carotenoid } \\
\text { content } \\
(\mu \mathrm{g} \mathrm{BC} / \mathrm{g})\end{array}$ \\
\hline Ipomoea batatas (red variety) & $37.28 \pm 4.27$ & $16.50 \pm 0.56$ & $0.43 \pm 0.00$ & $14.54 \pm 1.35$ \\
Ipomoea batatas (purple variety) & $52.18 \pm 5.68$ & $12.23 \pm 2.31$ & $3.08 \pm 1.07$ & $26.25 \pm 2.44$ \\
Manihot esculenta (periderm layer) & $42.86 \pm 3.88$ & $5.92 \pm 0.27$ & $0.87 \pm 0.72$ & $46.66 \pm 0.42$ \\
Manihot esculenta (cortex layer) & $71.79 \pm 5.57$ & $4.98 \pm 1.00$ & $3.03 \pm 0.94$ & $15.93 \pm 1.06$ \\
\hline
\end{tabular}

The results were expressed as mean \pm standard deviation in triplicate

with the value of $62.71 \mathrm{mg} / \mathrm{L}$. In addition, no samples contained zinc $(0 \mathrm{mg} / \mathrm{L})$ except for $M$. esculenta cortex layer which had almost zero value $(0.27 \mathrm{mg} / \mathrm{L})$. With the identification of the nutritional composition, it shows that the peels of the tubers have the potential to be developed as a new food product such as chips. Despite being thrown away as waste, this new food product can help the economics of the food industries. In fact, the previous study has developed new food product such as banana peel jelly which contained higher nutritional composition (Lee et al., 2010).

\subsection{Phytochemical content}

The results of the phytochemical content are presented in Table 3. M. esculenta (cortex layer) displayed the highest total phenolic content with the value of $71.79 \pm 5.57 \mu \mathrm{g}$ gallic acid equivalent $/ \mathrm{g}$ significantly different $(\mathrm{p}<0.05)$ to the other samples. Flavonoids are very effective antioxidants as it reduces the oxidation of low-density lipoproteins which helps in preventing cardiovascular diseases (Johnson and Williamson, 2003). Total flavonoid content was found to be highest in I. batatas (red variety) with the value of $16.50 \pm 0.56 \mu \mathrm{g}$ rutin equivalent/g significantly different than the other samples $(\mathrm{p}<0.05)$. A study on Annona cherimola Mill. (cherimoya) peel and pulp showed that the amount of total phenolic content and total flavonoid content in the peel were higher than in the pulp (Loizzo et al., 2012).

Anthocyanin is responsible for contributing a wide range of red, magenta, violet, purple, and blue colour towards the plants. Even though anthocyanin is less established compared to the other phytochemical, but it contributes commonly in food colorant (Tsuda, 2012).
The highest amount of total anthocyanin content with the value of $3.08 \pm 1.07 \mu \mathrm{g}$ cyanidin-3-glucoside equivalents/ $\mathrm{g}$ was obtained from I. batatas (purple variety) but the value showed no significant difference $(\mathrm{p}>0.05)$ with $M$. esculenta (cortex layer). The purple colour of the $I$. batatas peels (purple variety) itself might be the reason why it contained the highest total anthocyanin content in this study compared to other samples tested.

Abundant of carotenoids can be found in nature and $\beta$-carotene is one of it that has the ability as provitamin A in the human body (Fennema, 1996). Lycopene is one of the carotenoids aids in reducing the risk of cancer, arteriosclerosis, and coronary heart diseases (Sass-Kiss et al., 2005). M. esculenta (periderm layer) showed significant difference $(p<0.05)$ as compared to the other samples with the highest amount of total carotenoid content, $46.66 \pm 0.42 \mu \mathrm{g} \beta$-carotene/g.

\subsection{Antioxidant activity}

Table 4 shows the results of the antioxidant activity of the tubers peel. DPPH assay performs on the samples possess the mechanism of scavenging activity. I. batatas variety showed a significantly higher scavenging activity than $M$. esculenta. The highest activity was observed in I. batatas (purple variety) with the value of $87.93 \pm 7.91 \%$ and the lowest was observed in M. esculenta (periderm layer) with the value of $24.69 \pm 4.28 \%$.

In FRAP assay, the FRAP values obtained were lower for all the samples and they did not show any significant difference $(p>0.05)$ between each other. However, M. esculenta (cortex layer) displayed the slightly higher value of FRAP with $4.45 \pm 1.26 \mathrm{mM}$ ferric ion reduced/g.

Table 4. Antioxidant activity of the tubers peel

\begin{tabular}{cccc}
\hline & \multicolumn{3}{c}{ Antioxidant activity } \\
\cline { 2 - 4 } Sample & DPPH & FRAP & ABTS \\
\cline { 2 - 4 } & Scavenging activity (\%) & Ferric ion reduced (mM FE/g) & $\begin{array}{c}\text { Ascorbic acid equivalent } \\
(\mu \mathrm{g} \text { ascorbic acid/mL) }\end{array}$ \\
\hline Ipomoea batatas (red variety) & $87.62 \pm 5.20$ & $2.75 \pm 1.07$ & $37.38 \pm 0.38$ \\
Ipomoea batatas (purple variety) & $87.93 \pm 7.91$ & $2.81 \pm 0.63$ & $37.22 \pm 1.55$ \\
Manihot esculenta (periderm layer) & $24.69 \pm 4.28$ & $2.88 \pm 0.76$ & $35.40 \pm 1.31$ \\
Manihot esculenta (cortex layer) & $57.44 \pm 4.21$ & $4.45 \pm 1.26$ & $25.24 \pm 1.69$ \\
\hline
\end{tabular}

The results were expressed as mean \pm standard deviation in triplicate 
In ABTS assay, ABTS values were found to be highest in $I$. batatas varieties with $37.38 \pm 0.38 \mu \mathrm{g}$ ascorbic acid $/ \mathrm{mL}$ and $37.22 \pm 1.55 \mu \mathrm{g}$ ascorbic acid $/ \mathrm{mL}$, respectively for red and purple variety. The values were not found to be significantly different with $M$. esculenta (periderm layer) but had a significant difference $(\mathrm{p}<0.05)$ with $M$. esculenta (cortex layer) (25.24 $\pm 1.69 \mu \mathrm{g}$ ascorbic acid $/ \mathrm{mL}$ ).

\section{Conclusion}

In this study, both tubers, I. batatas and M. esculenta peel contained almost similar content of nutritional compositions. However, I. batatas showed higher mineral contents (potassium, iron, magnesium and sodium) and antioxidant activity than $M$. esculenta. For the phytochemical content, I. batatas contained higher total flavonoid and total anthocyanin contents while $M$. esculenta contained higher total phenolic and carotenoid contents. Both peels have great potential for use in complementary and alternative medicines as they are cheap and readily available. At the same time, the usage of the peels may aid in reducing the waste disposal problem and thus protecting the environment.

\section{Conflict of Interest}

The authors do not have any conflicts of interest regarding the content of the present work

\section{Acknowledgments}

The authors would like to thank Ministry of Education of Malaysia (MOE) for the research grant under Fundamental Research Grant Scheme (Vot: K099) as well as Universiti Tun Hussein Onn Malaysia for research grant support (Vot: U688, H277), the use of their laboratory facilities, and their assistance.

\section{References}

Abbasi, A., Shah, M. and Khan, M. (2014). Wild Edible Vegetables of Lesser Himalayas: Ethnobotanical and Nutraceutical Aspects. New York: Springer International Publishing. https://doi.org/10.1007/978 -3-319-09543-1

Abu Bakar, M.F., Ismail, N.A., Isha, A. and Ling, A.L.M. (2016). Phytochemical Composition and Biological Activities of Selected Wild Berries (Rubus moluccanus L., $R$. fraxinifolius Poir., and $R$. alpestris Blume). Evidence-Based Complementary and Alternative Medicine, 2016, 1-10. https:// doi.org/10.1155/2016/2482930

Adeyosoye, O.I., Adesokan, I.A., Afolabi, K.D. and Ekeocha, A.H. (2010). Estimation of proximate composition and biogas production from in vitro gas fermentation of sweet potato (Ipomoea batatas) and wild cocoyam (Colocasia esculenta) peels. African Journal of Environmental Science and Technology, 4 (6), 388-391.

Anhwange, B.A., Ugye, T.J. and Nyiaatagher, T.D. (2008). Chemical composition of Musa sapientum (banana) peels. Journal of Food Technology, 6(6), 263-266.

Aro, S.O., Aletor, V.A., Tewe, O.O. and Agbede, J.O. (2010). Nutritional potentials of cassava tuber wastes: A case study of a cassava starch processing factory in south-western Nigeria. Livestock Research for Rural Development, 22(11), 42-47.

Association of Official Analytical Chemists (AOAC). (1975). Official methods of analysis. 12th ed. Washington, DC, USA: AOAC.

Association of Official Analytical Chemists (AOAC). (1995). Official Methods of Analysis. 16th ed. Washington, DC, USA: AOAC.

Association of Official Analytical Chemists (AOAC). (2005). Official Methods of Analysis. 18th ed. Washington, DC, USA: AOAC.

Bhandari, M.R., Kasai, T. and Kawabata, J. (2003). Nutritional evaluation of wild yam (Dioscorea spp.) tubers of Nepal. Food Chemistry, 82(4), 619-623. https://doi.org/10.1016/S0308-8146(03)00019-0

Lusia, B.M., Hasmadi, M., Zaleha, A.Z. and Mohd Fadzelly, A.B. (2015). Effect of different drying methods on phytochemicals and antioxidant properties of unfermented and fermented teas from Sabah snake grass (Clinacanthus nutans Lind.) leaves. International Food Research Journal, 22(2), 661-670.

Elfalleh, W., Hannachi, H., Tlili, N., Yahia, Y., Nasri, N. and Ferchichi, A. (2012). Total phenolic contents and antioxidant activities of pomegranate peel, seed, leaf and flower. Journal of Medicinal Plants Research, 6(32), 4724-4730. https://doi.org/10.5897/ JMPR11.995

Fennema, O. (1996). Food chemistry. 3rd ed. New York: Marcel Dekker.

Ghasemzadeh, A., Omidvar, V. and Jaafar, H.Z. (2012). Polyphenolic content and their antioxidant activity in leaf extract of sweet potato (Ipomoea batatas). Journal of Medicinal Plants Research, 6 (15), 2971-2976. https://doi.org/10.5897/ JMPR11.1353

Johnson, I. and Williamson, G. (2003). Phytochemical Functional Foods. USA: CRC Press. https:// doi.org/10.1533/9781855736986

Lee, E.H., Yeom, H.J., Ha, M.S. and Bae, D.H. (2010). 
Development of banana peel jelly and its antioxidant and textural properties. Food Science and Biotechnology, 19(2), 449-455. https:// doi.org/10.1007/s10068-010-0063-5

Loizzo, M.R., Tundis, R., Bonesi, M., Menichini, F., Mastellone, V., Avallone, L. and Menichini, F. (2012). Radical scavenging, antioxidant and metal chelating activities of Annona cherimola Mill. (cherimoya) peel and pulp in relation to their total phenolic and total flavonoid contents. Journal of Food Composition and Analysis, 25(2), 179-184. https://doi.org/10.1016/j.jfca.2011.09.002

Miliauskas, G., Venskutonis, P.R. and Van Beek, T.A. (2004). Screening of radical scavenging activity of some medicinal and aromatic plant extracts. Food Chemistry, 85(2), 231-237. https://doi.org/10.1016/ j.foodchem.2003.05.007

Nawiri, M.P., Aywa, K. and Nyambaka, H.N. (2013). Nutrient variation in coloured varieties of Ipomea batatas grown in vihiga county western Kenya. International Food Research Journal, 20(2), 819825.

Nielsen, S. (2010). Food Analysis Laboratory Manual. 2nd ed. New York: Springer. https:// doi.org/10.1007/978-1-4419-1463-7

Nollet, L. (2004). Handbook of Food Analysis. 2nd ed. New York: Marcel Dekker.

Hassan, H.S.A and Bakar, M.F.A. (2013). Antioxidative and anticholinesterase activity of Cyphomandra betacea fruit. The Scientific World Journal, 2013, 17. https://doi.org/10.1155/2013/278071

Re, R., Pellegrini, N., Proteggente, A., Pannala, A., Yang, M. and Rice-Evans, C. (1999). Antioxidant activity applying an improved ABTS radical cation decolorization assay. Free Radical Biology and Medicine, 26(9-10), 1231-1237. https:// doi.org/10.1016/S0891-5849(98)00315-3

Sass-Kiss, A., Kiss, J., Milotay, P., Kerek, M.M. and Toth-Markus, M. (2005). Differences in anthocyanin and carotenoid content of fruits and vegetables. Food Research International, 38(8-9), 1023-1029. https:// doi.org/10.1016/j.foodres.2005.03.014

Tsuda, T. (2012). Dietary anthocyanin-rich plants: biochemical basis and recent progress in health benefits studies. Molecular Nutrition and Food Research, 56(1), 159-170. https://doi.org/10.1002/ mnfr.201100526

Wong, S.P., Leong, L.P. and Koh, J.H.W. (2006). Antioxidant activities of aqueous extracts of selected plants. Food Chemistry, 99(4), 775-783. https:// doi.org/10.1016/j.foodchem.2005.07.058 